\title{
Comparative activity of cefepime with several antimicrobials against aerobic Gram-negative and Gram-positive organisms isolated from patients across Canada in 1993
}

\author{
Donald E Low mD fRCPC, The CANadian Antimicrobial Resistance Study Group
}

\begin{abstract}
DE Low, The Canadian Antimicrobial Resistance Study Group. Comparative activity of cefepime with several antimicrobials against aerobic Gram-negative and Gram-positive organisms isolated from patients across Canada in 1993. Can $J$ Infect Dis 1995;6(5):258-262. To compare the activity of cefepime, a fourth-generation cephalosporin, with several available antimicrobials, in vitro susceptibility studies were carried out on bacteria commonly associated with various infections, including sepsis. Ten tertiary care hospital laboratories in six provinces provided 1276 clinically relevant isolates of aerobic Gram-negative bacilli and Gram-positive cocci during 1993. When the activity of each of the antimicrobials was determined against all isolates submitted, cefepime, piperacillin/tazobactam, imipenem and ciprofloxacin all had minimal inhibitory concentrations for $90 \%$ of the organisms (MIC90) two or more dilutions below the MIC resistant category. Gentamicin's MIC90 against all organisms tested was one dilution below the MIC resistant category. The MIC $90 \mathrm{~S}$ of the third-generation cephalosporins, piperacillin and ticarcillin/clavulanate, for Enterobacter species fell in the resistant category. This is presumably due to constitutive high level chromosomal cephalosporinase production. The MIC90S of cefepime for Enterobacter species was three or more dilutions below the MIC resistant category. The MIC90s of all antimcrobials against Staphylococcus aureus, with the exception of ceftazidime and piperacillin, had MIC90 categories two or more dilutions below the resistant category. The activity of cefepime, piperacillin/tazobactam, imipenem, ciprofloxacin and gentamicin make them excellent candidates for the empirical therapy of serious infections due to aerobic Gram-negative bacilli and S aureus. (Pour le résumé, voir page 259)
\end{abstract}

Key Words: Antimicrobial agents, Antimicrobial resistance, Cefepime, Surveillance

Department of Microbiology, Mount Sinai and Princess Margaret Hospitals, University of Toronto, Toronto, Ontario

The Canadian Antimicrobial Resistance Study Group: Anne-Marie Bourgault MD FRCPC, Hôpital St Luc, Montreal, Quebec; James Brunton MD FRCPC, The Toronto Hospital, Toronto, Ontario; Kevin Forward MD FRCPC, Victoria General Hospital, Halifax, Nova Scotia; Daryl Hoban PHD, Health Sciences Centre, Winnipeg, Manitoba; Jean R Joly MD FRCPC, St Sacrement Hospital, St-Foy, Quebec; Tom J Louie MD FRCPC, Calgary General Hospital, Calgary, Alberta; Vivian Loo MD FRCPC, Royal Victoria Hospital, Montreal, Quebec; Anne Phillips MD FRCPC, The Toronto Hospital, Toronto, Ontario; John A Smith MD FRCPC, Vancouver General Hospital, Vancouver, British Columbia

Correspondence and reprints: Dr DE Low, Department of Microbiology, Mount Sinai Hospital, 600 University Avenue, Room 1487, Toronto, Ontario M5G 1X5. Telephone 416-586-4435, fax 416-586-8746, e-mail low@mshri.on.ca

Received for publication April 4, 1995. Accepted May 31, 1995 


\section{Activité comparative de la céfépime et de divers antimicrobiens contre des organismes aérobies gram-négatifs et gram-positifs isolés chez des patients au Canada en 1993}

RÉSUMÉ : Pour comparer l'efficacité du céfépime, une céphalosporine de quatrième génération à celle des divers antimicrobiens offerts, des épreuves d'antibiogramme in vitro ont été effectuées sur les bactéries fréquemment associées à diverses infections, y compris la septicémie. Dix laboratoires d'hôpitaux de soins tertiaires, répartis dans six provinces, ont fourni 1276 isolats cliniquement pertinents de bacilles aérobies gram-négatifs et de cocci gram-positifs au cours de 1993. Lorsque l'activité de chacun des antimicrobiens a été mesurée sur tous les isolats soumis, la céfépime, la pipéracilline/tazobactame, l'imipénème et la ciprofloxacine ont tous présenté des concentrations inhibitrices minimales pour $90 \%$ des organismes (CMlgo) à deux dilutions ou plus sous la catégorie de CMı de la résistance. La CMlgo de la gentamycine contre tous les organismes testés était à une dilution sous la catégorie de CMI de la résistance. Les CMl90 des céphalosporines de troisième génération, pipéracilline et ticarcilline/clavulanate, pour Enterobacter sont tombées dans la catégorie de la résistance. Cela serait dû à une production inhérente de hauts taux de céphalosporinase chromosomique. Les CMlgo pour la céfépime à l'égard des Enterobacter a été de trois dilutions ou plus sous la catégorie de CMI de la résistance. Les CMlgo de tous les antimicrobiens à l'égard de Staphylococcus aureus, à l'exception de la ceftazidime et de la pipéracilline, étaient à deux dilutions ou plus sous la catégorie de la résistance. L'activité de la céfépime, de la pipéracilline/tazobactame, de l'imipénème, de la ciprofloxacine et de la gentamycine en font d'excellents candidats pour le traitement empirique des infections graves attribuables aux bacilles gram-négatifs aérobies et à S. aureus.

$\mathrm{S}$ ERIOUS BACTERIAL INFECTIONS RESULTING IN SEPSIS ARE ASsociated with significant morbidity and mortality $(1,2)$. Appropriate antibiotic therapy is critical in this condition and is considered the minimal standard of care (3). Since the initial choice of antimicrobial therapy is often empirical without the benefit of a culture report, let alone a susceptibility test result, it is essential to know what agents would be most effective in a given clinical diagnosis. This is especially important in the hospital setting where the patient is at risk of nosocomial infections due to antibiotic resistant pathogens. Patients with infections caused by bacteria resistant to the antimicrobial used for treatment have longer hospital stays and are at increased risk of death (4).

Cefepime is a new broad spectrum fourth-generation cephalosporin with significant in vitro antimicrobial advantages over other beta-lactam antimicrobials (5-9). In addition to a broad antimicrobial spectrum, cefepime has a low binding affinity for the major inducible chromosomally mediated betalactamases and can resist hydrolysis by beta-lactamases $(6,8,10,11)$. Cefepime is active in vitro against the major bacterial pathogens that cause infections of the lower respiratory tract, urinary tract, skin and soft tissue, and bacteremia, including those caused by Gram-negative bacteria and Grampositive bacteria $(5,8,11)$. Cefepime has limited activity against Gram-negative anaerobic bacilli (12). To determine the in vitro activity of cefepime and several available antimicrobials to bacterial strains isolated from hospitalized patients, 10 tertiary care hospital microbiology laboratories in six provinces were asked to provide clinically significant isolates for susceptibility testing.

\section{MATERIALS AND METHODS}

Participating laboratories were asked to collect approximately 100 consecutive bacterial isolates during 1993. Participants were asked to provide only nonduplicate isolates from specimens submitted from hospitalized patients that were considered clinically relevant and the source of which was evenly distributed from various sites. They were asked to provide additional strains of Enterobacter species, Serratia species, indole-positive Proteus species, Citrobacter freundii and Pseudomonas aeruginosa. They were also asked to provide additional isolates of Klebsiella species. Isolates were identified by standard methodologies (13). All isolates were subcultured twice before susceptibility testing.

Susceptibility testing: Broth microdilution was performed according to National Committee for Clinical Laboratory Standards guidelines (14). Microdilution panels were prepared by dispensing cation-supplemented Mueller-Hinton broth containing twofold-concentration increments of antimicrobial agents in $100 \mu \mathrm{L}$ plastic, 96-well trays. Inoculum suspensions equal to a $0.5 \mathrm{McF}$ arland standard were further diluted and added to the microdilution trays to achieve a final inoculum of $5 \times 10^{5}$ colony forming units (CFU)/mL. Colony counts were performed to confirm the final inoculum. Following inoculation, microdilution trays were incubated at $35^{\circ} \mathrm{C}$ in ambient air for 16 to $20 \mathrm{~h}$. After incubation, the minimal inhibitory concentration (MIC) was defined as the lowest concentration of antimicrobial with no evidence of growth. Cefepime (Bristol-Myers Squibb, Connecticut), piperacillin (Lederle Laboratories, New Jersey), piperacillin/tazobactam (Lederle Laboratories), cefotaxime (Hoechst-Roussel Pharmaceuticals Inc, New Jersey), ceftazidime (Glaxo, North Carolina), ceftriaxone (Hoffman-La Roche, Inc, New Jersey), ticarcillin/clavulanate (Beecham Laboratories, Tennessee) and imipenem (Merck Sharp and Dohme, New Jersey) were obtained. Gentamicin and ciprofloxacin powders were obtained from Sigma (Sigma Chemical Co, Missouri). Tazobactam was combined with piperacillin at a fixed concentration of $4.0 \mathrm{mg} / \mathrm{L}$. Clavulanic acid was combined with ticarcillin in a ratio of ticarcillin to clavulanate of 2:1. Escherichia coli ATCC 25922 and $P$ aeruginosa ATCC 27853 were used as control strains for broth microdilution testing.

The concentration of each antibiotic that inhibited $90 \%$ of the strains, MIC90, was determined only when 10 or more iso- 
TABLE 1

Interpretation of minimal inhibitory concentrations (MIC) of each antibiotic tested

\begin{tabular}{|c|c|c|c|}
\hline \multirow[b]{2}{*}{ Antimicrobial } & \multicolumn{3}{|c|}{ MIC (mg/L) } \\
\hline & $\mathbf{S}$ & I & $\mathbf{R}$ \\
\hline Cefepime & $\leq 8$ & 16 & $\geq 32$ \\
\hline Ceftazidime & $\leq 8$ & 16 & $\geq 32$ \\
\hline Cefotaxime & $\leq 8$ & $16-32$ & $\geq 64$ \\
\hline Ceftriaxone & $\leq 8$ & $16-32$ & $\geq 64$ \\
\hline Imipenem & $\leq 4$ & 8 & $\geq 16$ \\
\hline \multicolumn{4}{|l|}{ Piperacillin } \\
\hline $\begin{array}{l}\text { when testing Pseudomonas } \\
\text { aeruginosa }\end{array}$ & $\leq 64$ & - & $\geq 128$ \\
\hline $\begin{array}{l}\text { when testing other Gram- } \\
\text { negative organisms }\end{array}$ & $\leq 16$ & $32-64$ & $\geq 128$ \\
\hline \multicolumn{4}{|l|}{ Piperacillin/tazobactam } \\
\hline $\begin{array}{l}\text { when testing Pseudomonas } \\
\text { aeruginosa }\end{array}$ & $\leq 64$ & - & $\geq 128$ \\
\hline $\begin{array}{l}\text { when testing other Gram- } \\
\text { negative organisms }\end{array}$ & $\leq 16$ & $32-64$ & $\geq 128$ \\
\hline when testing staphylococci & $\leq 8$ & & $\geq 16$ \\
\hline \multicolumn{4}{|l|}{ Ticarcillin/clavulanic acid } \\
\hline $\begin{array}{l}\text { when testing Pseudomonas } \\
\text { aeruginosa }\end{array}$ & $\leq 64$ & - & $\geq 128$ \\
\hline $\begin{array}{l}\text { when testing other Gram- } \\
\text { negative organisms }\end{array}$ & $\leq 16$ & $32-64$ & $\geq 128$ \\
\hline when testing staphylococci & $\leq 8$ & - & $\geq 16$ \\
\hline Ciprofloxacin & $\leq 1$ & 2 & $\geq 4$ \\
\hline Gentamicin & $\leq 4$ & 8 & $\geq 16$ \\
\hline
\end{tabular}

I Intermediate; R Resistant; S Susceptible. Adapted from reference 8

lates of a species were tested. The MIC interpretive standards for the antimicrobials tested are listed in Table 1 (15).

\section{RESULTS}

In total, 1276 isolates were submitted for testing. The number of isolates sent by each centre ranged from 88 to 192 .
No specific pattern of resistance was noted in the individual hospitals participating in the study.

The activity of each of the antimicrobials tested against all isolates submitted is presented in Table 2 . The most active compounds were imipenem, with a MIC90 four dilutions below the resistance concentration breakpoint, and cefepime, piperacillin/tazobactam and ciprofloxacin, with MIc90s two dilutions below the resistance concentration breakpoints. Cefepime was the most active cephalosporin when tested against all isolates, with a MIC90 two dilutions below the resistance breakpoint.

The MIC90 of each of the antimicrobials to some of the species of organisms tested is presented in Table 3. The MIC90s of the third-generation cephalosporins were all $0.5 \mathrm{mg} / \mathrm{L}$ or less for E coli, Klebsiella pneumoniae, Klebsiella oxytoca and Proteus mirabilis, suggesting the absence of resistance due to extended spectrum plasmid-mediated beta-lactamase. Conversely, the high MIC90s of the third-generation cephalosporins against Enterobacter cloacae and Enterobacter aerogenes suggests that constitutive production of chromosomal beta-lactamase has become a significant problem in Canada and limits the effectiveness of these agents to treat infections due to these strains. Cefepime, however, was very active against these organisms, with MIC90 less than $1 \mathrm{mg} / \mathrm{L}$.

The most resistant strains tested were Staphylococcus haemolyticus and Staphylococcus epidermidis. The traditional antipseudomonal agents, ceftazidime, piperacillin and gentamicin, and the newer agents, cefepime, piperacillin/tazobactam, imipenem and ciprofloxacin, demonstrated good activity against $P$ aeruginosa.

\section{DISCUSSION}

The etiology of bloodstream infections were determined by Banerjee et al (16) from data reported by National Nosocomial Infections Surveillance system hospitals. They found that coagulase-negative staphylococci (CNST) were the most frequent cause of bloodstream infections, except in small

TABLE 2

The activity of each of the 10 parenterally administered antimicrobial agents against the 1276 isolates submitted from 10 medical centres across Canada in 1993

\begin{tabular}{|c|c|c|c|c|c|c|c|c|c|c|c|c|}
\hline \multirow[b]{2}{*}{ Antimicrobial } & \multicolumn{11}{|c|}{ Number of isolates for each MIC (mg/L) concentration } & \multirow[b]{2}{*}{$\%$ resistant } \\
\hline & $\leq 0.5$ & 1 & 2 & 4 & 8 & 16 & 32 & 64 & 128 & 256 & $>256$ & \\
\hline Cefepime & $915^{*}$ & 62 & 109 & 60 & $35^{\dagger}$ & 24 & $22^{\ddagger}$ & 11 & 38 & ND & ND & 6 \\
\hline Ceftazidime & $802^{*}$ & 62 & 61 & 28 & 118 & 37 & $43^{\dagger \ddagger}$ & 29 & 96 & ND & ND & 13 \\
\hline Cefotaxime & $772^{*}$ & 69 & 125 & 45 & 32 & 52 & $54^{\dagger}$ & $23^{\ddagger}$ & 104 & ND & ND & 10 \\
\hline Ceftriaxone & $766^{*}$ & 47 & 93 & 73 & 29 & 56 & 52 & $47^{\dagger \ddagger}$ & 113 & ND & ND & 13 \\
\hline Imipenem & $923^{*}$ & $240^{\dagger}$ & 36 & 37 & 3 & $4^{\ddagger}$ & 33 & ND & ND & ND & ND & 3 \\
\hline $\begin{array}{l}\text { Ticarcillin/ } \\
\text { clavulanic acid }\end{array}$ & ND & ND & 495 & $287^{*}$ & 90 & 75 & 94 & 87 & $50^{\dagger \ddagger}$ & 52 & 46 & 12 \\
\hline Ciprofloxacin & $1105^{*}$ & $56^{\dagger}$ & 28 & $19^{\ddagger}$ & 22 & 10 & 36 & ND & ND & ND & ND & 7 \\
\hline Gentamicin & ND & $1049^{*}$ & 32 & 35 & $47^{\dagger}$ & $68^{\ddagger}$ & 10 & 11 & 24 & ND & ND & 9 \\
\hline
\end{tabular}

MIC Minimal inhibitory concentration; ND Not done. ${ }^{*} M I C_{50}$, concentration at which $50 \%$ of organisms inhibited; ${ }^{\dagger} M I C_{90}$, concentration at which $90 \%$ of organisms inhibited; ${ }^{\ddagger}$ the MIC concentration that defines the resistant category 
TABLE 3

The concentration of 10 parenterally administered antimicrobial agents that inhibit $90 \%$ of aerobic Gram-negative and Gram-positive isolates submitted from 10 medical centres across Canada in 1993*

\begin{tabular}{|c|c|c|c|c|c|c|c|c|c|c|}
\hline \multirow[b]{2}{*}{ Organism (number) } & \multicolumn{10}{|c|}{$\mathrm{MIC}_{90}(\mathrm{mg} / \mathrm{L})^{\dagger}$} \\
\hline & Cefep & Ceftaz & Cefotax & Ceftriax & Imi & Pip & $\mathrm{P} / \mathrm{T}$ & $\mathrm{T} / \mathrm{C}$ & Cipro & Gent \\
\hline Escherichia coli (200) & $\leq 0.5$ & $\leq 0.5$ & $\leq 0.5$ & $\leq 0.5$ & $\leq 0.5$ & $>256^{\ddagger}$ & 4 & 64 & $\leq 0.5$ & $\leq 1$ \\
\hline Klebsiella pneumoniae (131) & $\leq 0.5$ & $\leq 0.5$ & $\leq 0.5$ & $\leq 0.5$ & $\leq 0.5$ & 16 & 8 & 8 & $\leq 0.5$ & $\leq 1$ \\
\hline Klebsiella oxytoca (19) & $\leq 0.5$ & $\leq 0.5$ & $\leq 0.5$ & $\leq 0.5$ & $\leq 0.5$ & $256^{\ddagger}$ & 8 & 16 & $\leq 0.5$ & $\leq 1$ \\
\hline Proteus mirabilis (24) & $\leq 0.5$ & $\leq 0.5$ & $\leq 0.5$ & $\leq 0.5$ & 2 & $>256^{\ddagger}$ & $\leq 2$ & $\leq 2$ & $\leq 0.5$ & 8 \\
\hline Enterobacter cloacae (236) & 1 & $64^{\ddagger}$ & $>64^{\ddagger}$ & $>64^{\ddagger}$ & 1 & $>256^{\ddagger}$ & 64 & $256^{\ddagger}$ & $\leq 0.5$ & $\leq 1$ \\
\hline Enterobacter aerogenes (49) & $\leq 0.5$ & 64 & 32 & $64^{\ddagger}$ & 1 & $128^{\ddagger}$ & 64 & $256^{\ddagger}$ & 2 & $\leq 1$ \\
\hline Serratia marcescens (101) & $\leq 0.5$ & 1 & 8 & 4 & 1 & 32 & 32 & 64 & 1 & $\leq 1$ \\
\hline Citrobacter freundii (61) & $\leq 0.5$ & 16 & 16 & 16 & 1 & $256^{\ddagger}$ & 32 & $256^{\ddagger}$ & $\leq 0.5$ & $\leq 1$ \\
\hline Citrobacter diversus (11) & 2 & 2 & 4 & 1 & $\leq 0.5$ & 16 & $\leq 2$ & 4 & $\leq 0.5$ & $\leq 1$ \\
\hline Morganella morganii (37) & $\leq 0.5$ & 16 & 16 & 4 & 4 & $128^{\ddagger}$ & $\leq 2$ & 32 & $\leq 0.5$ & $\leq 1$ \\
\hline Proteus vulgaris (27) & $\leq 0.5$ & 1 & 16 & $64^{\ddagger}$ & 4 & $128^{\ddagger}$ & $\leq 2$ & $\leq 2$ & $\leq 0.5$ & 2 \\
\hline Pseudomonas aeruginosa (52) & 8 & 4 & $>64^{\ddagger}$ & $>64^{\ddagger}$ & 1 & 32 & 16 & $128^{\ddagger}$ & 2 & 4 \\
\hline Staphylococcus aureus (106) & 4 & 16 & 4 & 4 & $\leq 0.5$ & $256^{\ddagger}$ & 4 & 4 & 1 & $\leq 1$ \\
\hline Staphylococcus epidermidis (53) & 16 & $64^{\ddagger}$ & 16 & 32 & 8 & 64 & 8 & $64^{\ddagger}$ & $>16^{\ddagger}$ & $16^{\ddagger}$ \\
\hline Staphylococcus haemolyticus (10) & $>64^{\ddagger}$ & $>64^{\ddagger}$ & $>64^{\ddagger}$ & $>64^{\ddagger}$ & $>16^{\ddagger}$ & $256^{\ddagger}$ & $256^{\ddagger}$ & $>256^{\ddagger}$ & $>16^{\ddagger}$ & $16^{\ddagger}$ \\
\hline
\end{tabular}

Cefep Cefepime; Cefotax Cefotaxime; Ceftaz Ceftazidime; Ceftriax Ceftriaxone; Cipro Ciprofloxacin; Gent Gentamicin; Imi Imipenem; MIC Minimal inhibitory concentration; Pip Piperacillin; P/T Piperacillin/tazobactam; T/C Ticarcillin/clavulanic acid. *MIC 90 was determined only when 10 or more isolates of a species were available; ${ }^{\dagger} \mathrm{MIC} 90$, the concentration at which $90 \%$ of the organisms are inhibited; ${ }^{\ddagger} \mathrm{MIC} 90$, concentrations that are in the resistant category

nonteaching hospitals, followed by aerobic Gram-negative bacilli and Staphylococcus aureus. Although CNST are often multiresistant, requiring vancomycin for effective therapy, waiting until a CNST is isolated and identified from a blood culture does not affect outcome $(17,18)$. However, it is essential that appropriate therapy be initiated as soon as possible for bloodstream infections due to aerobic Gram-negative bacilli and S aureus. Chamberland et al (19) determined the susceptibility of 941 aerobic Gram-negative bacilli isolated from the blood from septic patients in 10 Canadian hospitals during 1988. The most frequent species isolated were $E$ coli (52.5\%), K pneumoniae (11.2\%), $P$ aeruginosa (8.2\%), Serratia marcescens $(4.3 \%), P$ mirabilis $(3.9 \%), K$ oxytoca $(3.7 \%)$ and $E$ cloacae (3.6\%). The other 24 species each made up less than $2 \%$.

Even though aminoglycosides have been used clinically for four decades, they continue to have excellent in vitro activity. In Canada, Chamberland et al (19) in their 1988 study found rates of resistance of aerobic Gram-negative bacilli to gentamicin to be $2 \%$. In the present study, we continued to find similar rates of resistance in Enterobacteriaceae.

Following the introduction of extended spectrum cephalosporins, cephamycins, monobactams and carbapenems, increased resistance among the Gram-negative bacilli with inducible chromosomally mediated beta-lactamases were found $(20,21)$. These strains included Enterobacter species, Serratia species, indole-positive Proteus species, $C$ freundii and $P$ aeruginosa. These bacteria can undergo single-step mutations to constitutive high level production of this enzyme, which is capable of hydrolyzing second- and third-generation cephalosporins $(22,23)$. Although in our study we found MIC90S in the resistance range only among third-generation cephalosporins, piperacillin and ticarcillin/clavulanate against $E$ cloacae, $E$ aerogenes and $P$ vulgaris, other species with inducible chromosomally mediated beta-lactamase had reduced activity against these antimicrobials compared with those Gram-negative bacilli without this inducible beta-lactamase.

Resistance was not found with cefepime because of the low binding affinity of these beta-lactamases and its resistance to hydrolysis. In addition, cefepime has a slightly different penicillin binding protein target profile and a higher rate of penetration through outer membrane porins of Gramnegative bacteria compared with other cephalosporins. This and other studies have demonstrated that Gram-negative isolates that are resistant to one or more third-generation cephalosporins are susceptible to cefepime $(24,25)$.

\section{CONCLUSION}

Cefepime demonstrated excellent in vitro activity against those pathogens often causing serious bacterial infections and sepsis in the hospitalized patient and retained excellent activity to those isolates that demonstrated resistance to other antimicrobials, including third-generation cephalosporins.

ACKNOWLEDGEMENTS: This study was supported by a grant from Bristol-Myers Squibb.

\section{REFERENCES}

1. Bryan CS. Clinical implications of positive blood cultures. Clin Microbiol Rev 1989;2:329-53.

2. Setia U, Gross PA. Bacteraemia in a community hospital. Arch Intern Med 1977; 137:1698-701.

3. Gross PA, Barrett TL, Dellinger EP, et al. Quality standard for the treatment of bacteraemia. Clin Infect Dis 1994;18:428-30. 
4. Holmberg SD, Solomon SL, Blake PA. Health and economic impacts of antimicrobial resistance. Rev Infect Dis 1987;9:1065-78.

5. Clarke AM, Zemcov SJ, Wright JM. HR 810 and BMY-28142, two new cephalosporins with broad-spectrum activity: An in vitro comparison with other $\beta$-lactam antibiotics. J Antimicrob Chemother 1985;15:305-10.

6. Fuchs PC, Jones RN, Barry AL, Thornsberry C. Evaluation of the in vitro activity of BMY-28142, a new broad-spectrum cephalosporin. Antimicrob Agents Chemother 1985;27:679-82.

7. Kessler RE, Bies M, Buck RE, et al. Comparison of a new cephalosporin, BMY 28142, with other broad-spectrum $\beta$-lactam antibiotics. Antimicrob Agents Chemother 1985;27:207-16.

8. Neu HC, Chin NX, Jules K, Labthavikul P. The activity of BMY 28142 a new broad spectrum $\beta$-lactamase stable cephalosporin. J Antimicrob Chemother 1986;17:441-52.

9. Tsuji A, Maniatis A, Bertram MA, Young LS. In vitro activity of BMY-28142 in comparison with those of other $\beta$-lactam antimicrobial agents. Antimicrob Agents Chemother 1985;27:515-9.

10. Jacoby GA, Sutton L. Beta-lactamases and beta-lactam resistance in Escherichia coli. Antimicrob Agents Chemother 1985;27:703-5.

11. Phelps DJ, Carlton DD, Farrell CA. Affinity of cephalosporins for $\beta$-lactamases as a factor in antimicrobial efficacy. Antimicrob Agents Chemother 1986;29:845-8.

12. King A, Boothman $C$, Phillips I. Comparative in vitro activity of cefepirome and cefepime, two new cephalosporins. Eur J Clin Microbiol Infect Dis 1990;9:677-85.

13. Farmer JJ, Kelly MT. Enterobacteriaceae. In: Balows A, Hausler WJ, Herrmann KL, et al, eds. Manual of Clinical Microbiology, 5 th edn. Washington: American Society for Microbiology, 1991:360-83.

14. National Committee for Clinical Laboratory Standards. Methods for dilution antimicrobial susceptibility tests for bacteria that grow aerobically. Approved standard M7-A3. Villanova: National Committee for Clinical Laboratory Standards, 1993.

15. National Committee for Clinical Laboratory Standards.
Performance standards for antimicrobial susceptibility testing. Approved standards M100-S5. Villanova: National Committee for Clinical Laboratory Standards: 1994.

16. Banerjee SN, Emori TG, Culver DH, et al. Secular trends in nosocomial primary bloodstream infections in the United States, 1980-1989. Am J Med 1991;9(Suppl 3B): 3B-86S.

17. European Organization for Research and Treatment of Cancer (EORTC) International Antimicrobial Therapy Cooperative Group and the National Cancer Institute of Canada - Clinical Trials Group: Vancomycin added to empirical combination antibiotic therapy for fever in granulocytopenic cancer patients. J Infect Dis 1991;163:951-8.

18. Ramphal R, Bolger M, Oblon DJ, et al. Vancomycin is not an essential component of the initial empiric treatment regimen for febrile neutropenic patients receiving ceftazidime: a randomized prospective study. Antimicrob Agents Chemother 1992;36:1062-7

19. Chamberland S, L'Ecuyer J, Lessard C, et al. Antibiotic susceptibility profiles of $941 \mathrm{Gram}$-negative bacteria isolated from septicemic patients throughout Canada. Clin Infect Dis 1992;15:615-28.

20. Bush K. Characterization of beta-lactamases. Antimicrob Agents Chemother 1989;33:259-63.

21. Bush K. Classification of -lactamases: group 1, 2a, 2b, and 2b'. Antimicrob Agents Chemother 1989;33:264-70.

22. $\mathrm{Vu} \mathrm{H}$, Nikaido $\mathrm{H}$. Role of $\beta$-lactam hydrolysis in the mechanism of resistance of a $\beta$-lactamase-constitutive Enterobacter cloacae strain to extended-spectrum $\beta$-lactams. Antimicrob Agents Chemother 1985;27:393-8.

23. Korfman G, Wiedemann B. Genetic control of $\beta$-lactamase production in Enterobacter cloacae. Rev Infect Dis 1988; 10:793-9.

24. Thornsberry C, Brown SD, Yee YC, et al. In vitro activity of cefepime and other antimicrobial: survey of European isolates. $J$ Antimicrob Chemother 1993;32(Suppl B): 31-53.

25. Duval J, Soussy CJ, Acar JF, et al. In vitro antibacterial activity of cefepime: a multicentre study. J Antimicrob Chemother 1993;32(Suppl B):81-6. 


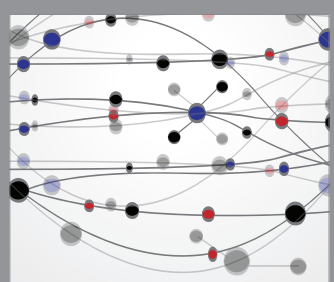

The Scientific World Journal
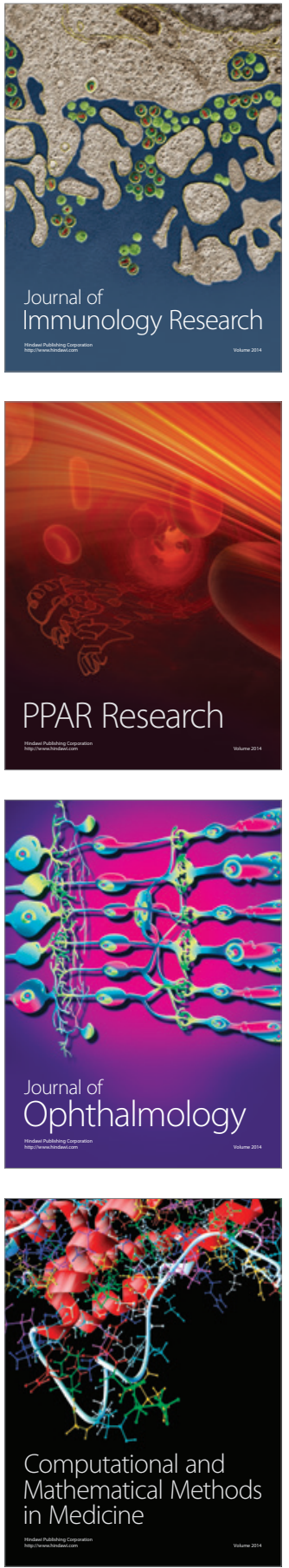

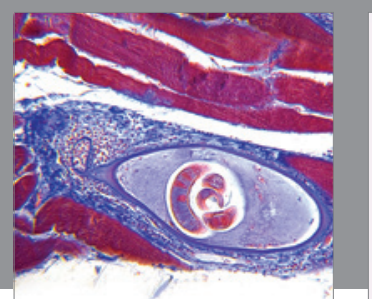

Gastroenterology Research and Practice

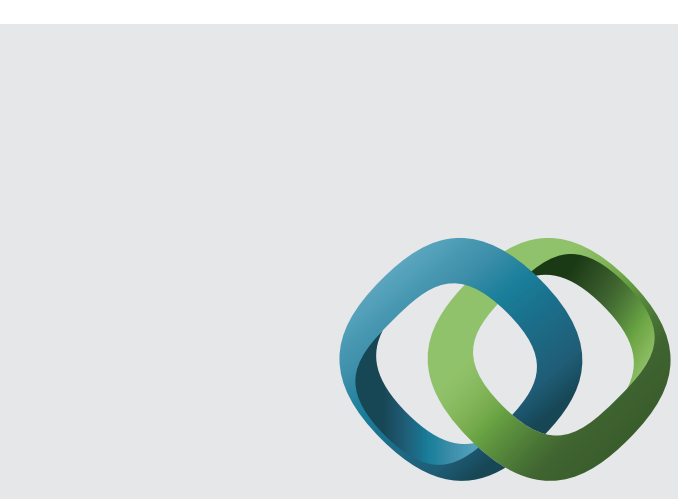

\section{Hindawi}

Submit your manuscripts at

http://www.hindawi.com
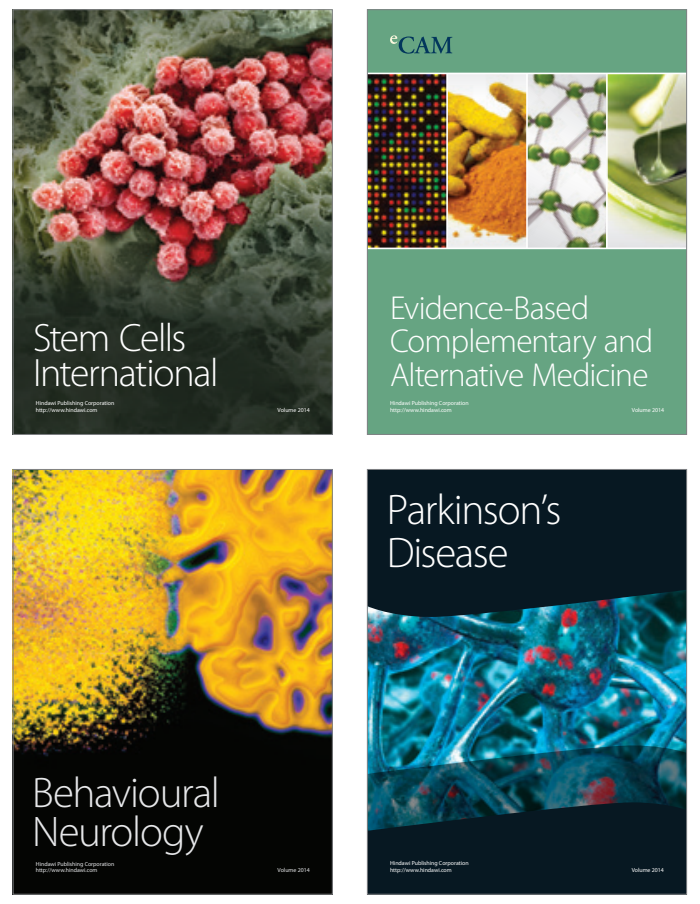
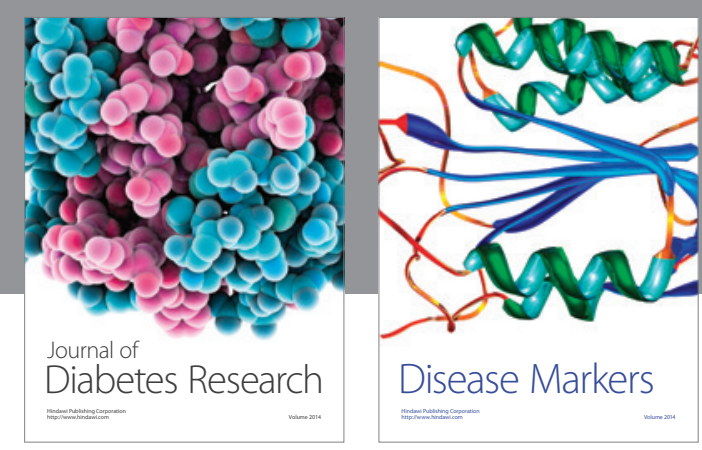

Disease Markers
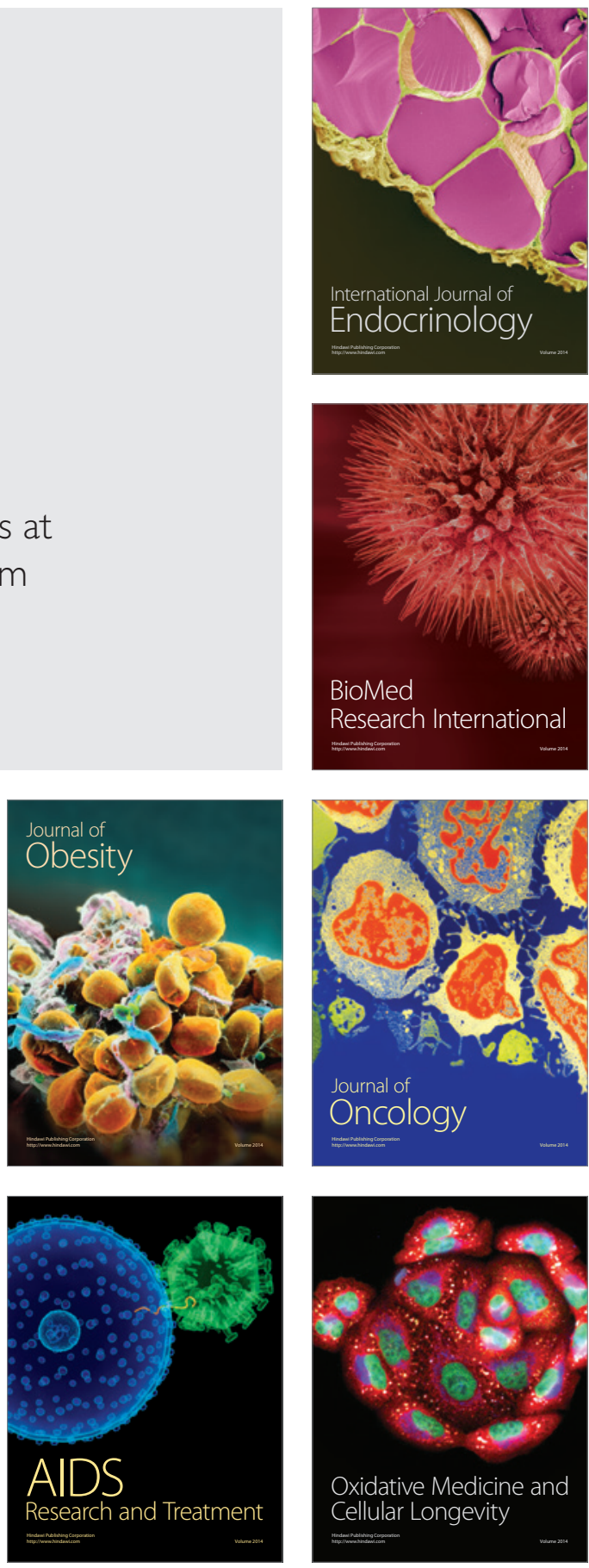